time - as much as 18 hours - for a ground-launched missile to reach them and knock them out.

The peculiar and varying orbits, and the use of "dormant" satellites as reserves, could make it very difficult for a Soviet antisatellite system to knock them all out. In short, the warning system itself would contribute to security, by buying leaders more time.

The report also suggested that communications links could be maintained in a variety of ways: satellite communications could use millimetre wavelengths to avoid ionospheric disturbances due to high-altitude nuclear explosions. Rocket-launched reconstitution satellites could be on ready alert; existing communications satellites could be prepared to serve as back-ups. An LUA communications net would have an advantage over the alternative communications nets for other MX options, in that its most crucial period of use would be before the atmosphere was disrupted by nuclear attack.

In sum, the OTA report foresaw a future LUA system resilient enough to warn of a major attack - such as the lightning boltfrom-the-blue that the MX is meant to counter. The report implies that the President would not be faced with only a few minutes to think, panicked generals and blinking machines, but a relatively well ordered set of options: knowledge through earlywarning of anti-satellite efforts, time to use the "hot line", and sure information about the attack itself. The report went so far as to suggest a series of automatic LUA programmes for response, that might not need the President's decision, in case he was incapacitated or unavailable.

Garwin takes this one step farther. If the United States had an announced, self-evident and reliable capability for LUA, the Soviet Union should be deterred from ever attempting to attack, he says. In attacking, the Soviet Union would have to launch its missiles all at once to minimize US foreknowledge. Thus, submarine-launched missiles would start hitting US bomber bases and US submarines in port 5 to 15 minutes after the launch, when the long-range ICBMs still had 15 minutes or more to go before reaching their targets.

All the President needs to be able to do, Garwin argues, is to certify that this attack is under way, based on information his machines can surely provide. He would then authorize a preplanned launch of the US land-based ICBMs, his only surviving force. If the Soviet Union realized how automatic and surely this retaliation would come, Garwin says, it would be deterred from attacking in the first place, even against the vulnerable force of US land-based ICBMs. Thus for Garwin, LUA is the solution to the problem of Minuteman vulnerability.

Garwin's proposed LUA policy, with its elements of automatic response and certainty of destruction of the attacking side thus has much in common with MAD - the 1960 s doctrine of "mutual assured destruction" under which the United States (which then had less accurate weapons than it does now) pledged to destroy Soviet industry and society if it were ever attacked. One way to look at a possible LUA policy, therefore, is as a high-precision version of MAD.

Is all this technological hubris of the first order? What sane president, or sane society, would entrust the decision about its likely end almost entirely to machines? If the warning could not be made reliable, LUA could make a mockery of human judgement and morality.

But if technology has evolved to the point where the machinery could be made reliable we must think again. Should we decline to upgrade strategic warning, and decide not to give leaders the best information they can get? What sane president, faced with a possible nuclear attack, would want to turn the calculations over to rows of men with abacuses to make sure the "human element" was not lost in the final decision? Every day, jetliners carry innocent passengers across oceans and continents on automatic pilot systems, yet this is not morally outrageous, so long as the pilot is there to back up the machines.

A society that has already delegated so much to technology, ought, when it comes to make a final choice, to consider technology an ally, too.

\section{An almighty crash}

\section{AEG brought about its own collapse, but there are lessons for all to learn}

The collapse last week of the West German corporation AEGTelefunken has been on the cards for more than a decade, but is none the less to be mourned on that account. The seventh largest corporation in West Germany, AEG-Telefunken is a monument to the optimism of the $1950 \mathrm{~s}$ and $1960 \mathrm{~s}$, so that its decision to appeal to the courts for relief from three-fifths of its still unspecified debts marks the passing of an era. For much of the past twenty years, AEG-Telefunken had around its neck the albatross of its 40 per cent share in Kraftwerk-Union, the nuclear construction consortium - until Siemens obligingly bought it out in 1978. During the same period, but especially at the beginning of it, AEG seems accurately to have appreciated that high technology was waiting around every corner and to have determined to be strongly represented in them all. So was it just bad luck that it was not then possible to guess how high would be the cost of development in most of these new fields; or that technological conglomerates would become unfashionable; and that they would prove to be so hard to manage?

Hardly. Compared with Siemens, the obvious analogue, AEG has been run by accountants rather than by technologists. They have been skilled at raising extra capital - no less than DM1,000 million in 1979 from the West German banks, for example - but apparently less skilled at matching their technical ambitions to reality. Even so, the efforts they have made in the past three years to sell off parts of the business, and to form joint ventures with other corporations (as with Bosch over telecommunications) have been insufficient. The most obvious difficulty has been that AEG has not been technically outstanding in any of the fields in which it has taken an interest. The moral, for other corporations, should be familiar. A technically based conglomerate, however large, can survive in the long run only by technical excellence.

To many outside West Germany, it has been a surprise that one of the impediments to the reconstruction of AEG has been the resistance of the labour unions to the threat of redundancy, one of the reasons why the British General Electric Company last week pulled out of negotiations about a partnership with AEG in the manufacture of heavy electrical machinery. Despite the record of harmonious industrial relations in West Germany since the Second World War, it should be no surprise that unions are less compliant with their employers' needs on the downturn than they were during the economic miracle. But the prospect now is that AEG will have to shed at least 40,000 of the 100,000 people it employs in West Germany and perhaps an even larger proportion of its 20,000 employees elsewhere. It is almost too much to ask that flesh and blood should stomach redundancies on such a scale. Represented as they are by law on the supervisory board of $\mathrm{AEG}$, the unions have behaved predictability. Elsewhere governments have stepped in to avoid trouble of this kind (as at Chrysler and British Leyland).

So what will be the consequences of the decline of AEG? Those who will lose their jobs, like those who have lost a large part of their investment in the company, will be more than merely inconvenienced. So too in the short run will be the host of smaller companies working as suppliers for AEG. Its competitors will now find the market for their goods more buoyant and more easily attacked. The business that AEG is forced to shed will in due course be picked up by others, with the result that some of those now destined to lose their jobs will be re-employed. In the long run, there will be two conspicuous losers. First, the legend of West German industrial cleverness will be permanently tarnished. Second, Chancellor Helmut Schmidt's coalition government, which has steadfastly declined to intervene on AEG's behalf (and which was politically and economically powerless to intervene) will be unfairly blamed by its opponents for not having lifted a finger and for having created the economic climate that brought AEG to its knees. 